\title{
Extenuating role of lycopene against 254-nm UV-C radiation-mediated damages in Allium cepa L. roots
}

\author{
Dilek Çavuşoğlu ${ }^{1} \cdot$ Tuğçe Kalefetoğlu Macar ${ }^{2} \cdot$ Oksal Macar $^{2} \cdot$ Emine Yalçın $^{3} \cdot$ Kültiğin Çavuşoğlu ${ }^{3}$
}

Received: 6 January 2021 / Accepted: 19 April 2021 / Published online: 23 April 2021

(C) The Author(s), under exclusive licence to Springer-Verlag GmbH Germany, part of Springer Nature 2021

\begin{abstract}
UV-C exposure has become a crucial risk for living organisms due to its widespread use in sterilization. In this study, the mitigating potential of lycopene was investigated against UV-C-mediated toxicity in Allium cepa L. roots. Allium bulbs were separated into six groups which treated with tap water, $215 \mathrm{mg} / \mathrm{L}$ lycopene, $430 \mathrm{mg} / \mathrm{L}$ lycopene, 254-nm UV radiation, $215 \mathrm{mg} / \mathrm{L}$ lycopene + 254-nm UV radiation, and $430 \mathrm{mg} / \mathrm{L}$ lycopene + 254-nm UV radiation. Germination percentage, root length, weight gain, mitotic index, micronucleus frequency, and other chromosomal aberrations as well as meristematic cell damages were investigated in all groups. Malondialdehyde level and the activities of superoxide dismutase and catalase enzymes were also analyzed to understand the severity of oxidative stress. UV-C radiation was revealed to negatively affect all parameters investigated, while the mitigating activities of lycopene against UV-C-mediated toxicity were dose-dependent. Therefore, the study evidently demonstrated the promising potential of lycopene in the protection against the detrimental effects of UV-C exposure in A. сера.
\end{abstract}

Keywords Allium cepa $\cdot$ Genotoxicity $\cdot$ Lycopene $\cdot$ Meristematic cell damages $\cdot$ Oxidative stress $\cdot$ UV radiation

\section{Introduction}

The thinning of the ozone layer in the stratosphere causes a large increase in ultraviolet (UV) radiation on the earth's surface (Bernhard et al. 2020). Sunlight consist of three types of UV radiation including UV-A (315-400-nm wavelength), UV-B (280-315-nm wavelength), and UV-C (200-280-nm wavelength). UV is a carcinogen with well-known genotoxic and mutagenic effects (Szoltysek et al. 2017). DNA damage arising from UV irradiation may occur due to the direct and indirect effects of UV. Direct damage is related to covalent modification of neighboring pyrimidines, whereas indirect

Responsible Editor: Gangrong Shi

Tuğçe Kalefetoğlu Macar

tugce.macar@giresun.edu.tr

1 Department of Plant and Animal Production, Atabey Vocational School, Isparta Applied Sciences University, 32200 Isparta, Turkey

2 Department of Food Technology, Șebinkarahisar School of Applied Sciences, Giresun University, 28400 Giresun, Turkey

3 Department of Biology, Faculty of Science and Art, Giresun University, 28049 Giresun, Turkey damage is related to reactive oxygen species (ROS) accumulation (Yu and Lee 2017). The detrimental effect of UV-A on DNA is due to indirect damage associated with excessive ROS production. On the other hand, UV-B and UV-C cause direct damage to cellular DNA by forming photodimers in dipyrimidine regions (Mullenders 2018). It has also been shown that UV-C light stimulates ROS formation, which has the potential to directly damage DNA and other macromolecules (Szoltysek et al. 2017). Although UV irradiation seems to be a panacea, especially in sterilization, cancer therapy, and food preservation studies, different types of UV radiation have substantial disadvantages. Because UV-A induce sub-lethal damages rather than killing cells, it has a lower germicidal activity than UV-B and UV-C (Jeon and Ha 2018). Unlike UV-A and UV-B, surfaces must be cleaned of visible organic contamination prior to UV-C disinfection, as UV-C has poor penetrability due to its high absorption potential by organic materials (Andersen et al. 2006). In addition, the necessity of placing the UV-C unit very close to the target during food preservation processes was also considered as a disadvantage (GuerreroBeltrán and Barbosa-Cánovas 2004). Although the vast majority of UV-C is absorbed by the ozone layer, humans are exposed to this type of radiation from artificial sources such as fluorescent lamps, light-emitting diodes, and mercury vapor 
lamps (Kaidzu et al. 2019). Microorganisms and plants are severely damaged by UV-C. Because the wavelength of $254 \mathrm{~nm}$ is extremely close to the peak of DNA absorption $(253.7 \mathrm{~nm})$ and microorganisms such as bacteria, fungi, viruses, and spores can be successfully eliminated at this wavelength, 254-nm wavelength of UV-C radiation is frequently used in sterilization applications (Coohill and Sagripanti 2008; Lindblad et al. 2020). It is also known that low-dose UV-C application increases the shelf life of fruits and vegetables by causing stress and stress-induced antioxidant metabolite synthesis in plants (Park and Kim 2015). Despite its important uses, UV-C radiation is cytotoxic, harmful to the human cornea, and promoting malignant tumor formation (Kaidzu et al. 2019; Fukui et al. 2020).

Lycopene $\left(\mathrm{C}_{40} \mathrm{H}_{56}\right)$ is a highly unsaturated carotenoid compound mostly found in reddish- and orange-colored fruits and vegetables (Yin et al. 2019). The inability of the human body to synthesize lycopene makes it necessary to take lycopene from the diet. Tomato, watermelon, red oranges, pink grapefruits, carrot, pomegranate, red grapes, and papaya as well as tomato-derived foods such as soup, sauces, tomato juice, and ketchup are the major sources of dietary lycopene intake (Bramley 2000; Kong et al. 2010; Imran et al. 2020). As a strong antioxidant phytochemical, it deactivates ROS effectively (Imran et al. 2020). It should be noted that the highest antioxidant power among carotenoid pigments belongs to lycopene. Indeed, lycopene has proven to be a marvelous nutraceutical which has positive effects in cancer, cardiovascular diseases, infertility, liver dysfunctions, and metabolic syndrome (Grabowska et al. 2019; Caseiro et al. 2020).

Plant-based systems, including Allium cepa $\mathrm{L}$. assay, have been widely used in determining the cytotoxicity and genotoxicity from a variety of contaminants and other risk factors, as well as evaluating the preventive potential of natural products (Roy et al. 2019; Macar et al. 2020). Thanks to its vulnerable roots with highly active meristematic activity, A. cepa provides a practical, inexpensive, and sensitive assessment method exhibiting perfect compatibility with other test systems including rodents (Srivastava and Singh 2020).

Especially with the COVID-19 pandemic, the increased use of UV-C radiation in decontamination and sterilization studies makes it necessary to identify functional foods that are protective against UV-C exposure-related health problems. Therefore, the present study was aimed to evaluate the preventive potential of lycopene against the damages caused by $254-\mathrm{nm}$ UV-C radiation via a model organism, A. серa. Besides genotoxicity parameters (mitotic index (MI), micronucleus (MN) formation, and chromosomal aberrations (CAs)), some physiological (germination percentage, root length, and weight gain) and biochemical parameters (malondialdehyde (MDA) content and the total activities of superoxide dismutase (SOD) and catalase (CAT) enzymes) were monitored in order to present a comprehensive research.
The meristematic cell damages caused by UV-C administration and the mitigating effect of lycopene on these damages were also investigated.

\section{Materials and methods}

\section{Design of the experiment}

Equal-sized (4.97-5.15 g) A. cepa bulbs were purchased from local markets in Isparta, Turkey. Bulbs were thoroughly washed under tap water, and then dry roots and outer scales were taken away. Six groups of 50 individuals each were formed with the peeled bulbs. The first group (G1) was considered as control and soaked in a glass beaker filled with tap water throughout the experimental period. The other groups were treated with 215 $\mathrm{mg} / \mathrm{L}$ lycopene (G2), $430 \mathrm{mg} / \mathrm{L}$ lycopene (G3), 254-nm UV radiation (G4), $215 \mathrm{mg} / \mathrm{L}$ lycopene + 254-nm UV radiation (G5), and $430 \mathrm{mg} / \mathrm{L}$ lycopene + 254-nm UV radiation (G6) for 3 days at room temperature. Lycopene solutions were prepared using Sepe Natural Lycopene Extract ( 90 capsule $\times 430 \mathrm{mg}$ ) (Sepe Natural Organic Products San. ve Tic. A.Ș., İzmir, Turkey). Capsules enclosed with edible bovine serum gelatin were filled with lycopene extract obtained from Solanum lycopersicum and Ginkgo biloba leaf powders. Administration of 254-nm radiation to the UV-treated groups (groups 4, 5, and 6) was performed using a hand-held UV lamp (Model UVGL-58, Mineralite, UVP, Upland, CA, USA) for 3 days. UV-C radiation was applied to the beakers containing the bulbs from a distance of $20 \mathrm{~cm}$ from the top. During the UV application, bulbs in group 4 were in contact with tap water, and bulbs in groups 5 and 6 were in contact with $215 \mathrm{mg} / \mathrm{L}$ lycopene and $430 \mathrm{mg} / \mathrm{L}$ lycopene solutions, respectively.

\section{Assessment of growth levels}

When the experimental period was over, germination was monitored considering the emergence of the new roots from the disc stem of each bulb. Germination percentage (\%) was calculated using the formula (Eq. 1) (Atik et al. 2007).

GP $(\%)=($ Number of the germinated bulbs/Total number of the bulbs) $\times 100(1)$

Lengths of the new roots $(\mathrm{cm})$ were measured with a ruler from basis to tips at the end of the treatments. Pre-application and post-application weights of bulbs $(\mathrm{g})$ were noted to determine the effects of the treatments on growth. The difference between final weight and initial weight was recorded as weight gain $(\mathrm{cm})$. 


\section{Assessment of genotoxicity parameters}

At the end of the experimental process, $0.5-1-\mathrm{cm}$-long root segments were cut from the end of the roots and pre-treated with saturated para-dichlorobenzene solution for $4 \mathrm{~h}$. Root tips were then transferred into acetic-alcohol (1:3) solution for fixation for $24 \mathrm{~h}$. Samples were stored at $+4{ }^{\circ} \mathrm{C}$ in $70 \%$ alcohol until the analysis began (Hill and Myers 1945). Hydrolysis of the tissues was achieved by keeping the roots in $1 \mathrm{~N} \mathrm{HCl}$ in a hot water bath set at $60^{\circ} \mathrm{C}$ for $17 \mathrm{~min}$. Root tips were then thoroughly washed with tap water and kept in Feulgen stain for $1-1.5 \mathrm{~h}$ for staining. Following the staining process, the root tips were washed with tap water once again for $15 \mathrm{~min}$. One drop of acetic acid was used before squashing the roots to prepare the microscopic slides (Sharma and Gupta 1982). Slides were screened (500X) to evaluate MI and the frequency of CAs and MN under a microscope (Olympus CX41) and photographed using a camera (Olympus C-5060). One hundred cells from each root tip and totally 1000 cells from each group were scored for MN and CAs frequencies. MN bodies were identified according to the criteria suggested by Fenech et al. (2003). On the other hand, MI was analyzed considering 1000 cells from each root tip and totally 10,000 cells from each group. MI was scored by proportioning the number of cells that underwent mitosis to the total number of dividing and non-dividing cells.

\section{Assessment of biochemical parameters}

The total activities of SOD ([EC 1.15.1.1]) and CAT ([EC 1.11.1.6]) enzymes as well as MDA content were evaluated after the treatments were ended.

MDA, a decisive marker of oxidative stress-related membrane damages, was evaluated according to Heath and Packer (1968). For MDA analysis, $0.1 \mathrm{~g}$ of root segments was ground and homogenized using $2 \mathrm{~mL}$ of $5 \%$ trichloroacetic acid (TCA). After a 15-min centrifugation process at 12,000 rpm, supernatant fraction of the samples $(1 \mathrm{~mL})$ was mixed with an equal amount of $0.5 \%$ thiobarbituric acid (TBA) in $20 \%$ TCA. All processes were carried out at $25^{\circ} \mathrm{C}$. Sample mixtures were exposed to $95^{\circ} \mathrm{C}$ temperature for 25 min utilizing a hot water bath. Ice bath was used to terminate the reactions. The samples were kept in the ice bath for $10 \mathrm{~min}$ to cool completely. Following a 5-min centrifugation process at 10,000 rpm, absorbance of the supernatant collected from the samples at $532 \mathrm{~nm}$ and $600 \mathrm{~nm}$ were recorded using a spectrophotometer (Shimadzu Mini-1240 / UV-Vis spectrophotometer). The absorbance at $600 \mathrm{~nm}$ was utilized to distinguish the nonspecific turbidity. MDA contents of the samples were calculated as micromolars per gram of fresh weight (extinction coefficient $155 \mathrm{mM} . \mathrm{cm}^{-1}$ ).

Extraction process of the enzymes (SOD and CAT) was carried out using the same method (Zou et al. 2012). $0.5 \mathrm{~g}$ of root segment was transferred to an ice-cold mortar containing $0.05 \mathrm{M}$ sodium phosphate buffer with $\mathrm{pH} 7.5$ after pretreatment in liquid nitrogen for $30 \mathrm{~s}$. Twenty-minute centrifugation at $14,000 \mathrm{rpm}$ at $+4{ }^{\circ} \mathrm{C}$ was applied to separate the supernatant fraction of homogenates.

The total activities of SOD and CAT enzymes were evaluated using the methods of Beauchamp and Fridovich (1971) and Zhang et al. (2005), respectively. A mixture consisting of $0.01 \mathrm{~mL}$ of supernatant, $1.5 \mathrm{~mL}$ of $0.05 \mathrm{M}$ sodium phosphate buffer with $\mathrm{pH} 7.8,0.28 \mathrm{~mL}$ of distilled water, $0.3 \mathrm{~mL}$ of $20 \mu \mathrm{M}$ riboflavin, $0.3 \mathrm{~mL}$ of $130 \mathrm{mM}$ methionine, $0.3 \mathrm{~mL}$ of $750 \mu \mathrm{M}$ nitro blue tetrazolium chloride, $0.3 \mathrm{~mL}$ of $0.1 \mathrm{mM}$ EDTA- $\mathrm{Na}_{2}$, and $0.01 \mathrm{~mL}$ of $4 \%$ polyvinylpyrrolidone was prepared in a spectrophotometer cuvette and allowed to react for $15 \mathrm{~min}$ under $375 \mu \mathrm{mol} \mathrm{m}{ }^{-2} \mathrm{~s}^{-1}$ fluorescent light to assess the total SOD activity. The absorbance of the mixture at 560-nm wavelength recorded by a Shimadzu Mini-1240/UVVis spectrophotometer was utilized to calculate the total SOD activity of the samples (unit $\mathrm{mg}^{-1}$ fresh weight).

A mixture consisting of $0.05 \mathrm{M}$ sodium phosphate buffer with $\mathrm{pH} 7.8$, distilled water and $0.1 \mathrm{M}$ hydrogen peroxide $\left(\mathrm{H}_{2} \mathrm{O}_{2}\right)$ was prepared in a spectrophotometer cuvette to assess the total CAT activity. Enzymatic reaction was allowed to run by adding the $0.2 \mathrm{~mL}$ supernatant to the mixture and was monitored by the decrease in absorbance measured at 240$\mathrm{nm}$ wavelength (Shimadzu Mini-1240/UV-Vis spectrophotometer). The total enzymatic activity of CAT enzyme was calculated as OD240nm min $\mathrm{g}^{-1}$ fresh weight.

\section{Assessment of meristematic cell damages}

Freshly prepared cross-section of the decapitated root segments was stained with 1 drop of methylene blue (1\%) to determine the damage level of meristematic cell. A steel scalpel was used to take the cross sections. Slides were screened under a $\times 500$ magnification of a microscope (Olympus CX41) and photographed using a camera (Olympus C-5060). At the end of the examination, meristematic injuries were classified according to their intensity.

\section{Statistical analysis}

Data were shown as mean \pm standard deviation in the tables. The means of the data were compared in terms of statistical differences using one-way ANOVA and Duncan's tests ( $p$ $<0.05$ ). SPSS 23 software was used to carry out statistical analysis.

\section{Results and discussion}

Potential effects of UV-C and lycopene on physiological parameters were evaluated considering germination, root 
elongation, and weight increase of the bulbs (Table 1). While the lycopene-treated groups (G2 and G3) showed 100\% germination success as the control group (G1), the germination percentage of G4 treated with UV-C radiation was determined as $63 \%$. Low-dose lycopene applied with UV-C led to an increase in the germination percentage in G5. The raise in the germination rate in G6 was greater than in G5. Similar to the germination percentage results, both the root elongation and the weight gain values in $\mathrm{G} 2$ and $\mathrm{G} 3$ treated with lycopene solutions were not statistically different from G1. UV-C treatment triggered a stunning reduction in the root elongation rate in $\mathrm{G} 4$ compared to G1. Similarly, the weight gain in the group exposed to UV radiation (G4) also drastically declined. On the other hand, the elongation rate of the root and the weight gain of the bulbs in UV-C-exposed groups (G5 and G6) showed a gradual increase with increasing lycopene doses. Lycopenetreated G2 and G3 groups, which achieved similar results to the control, indicated that lycopene administration had no side effects on growth. Various studies on higher plants have shown that excessive UV radiation causes different morphological and physiological responses (Golob et al. 2017; Verdaguer et al. 2017; Yadav et al. 2020; Forges et al. 2020). Neelamegam and Sutha (2015) reported that UV-C irradiation treatment had no detrimental effect on seed germination and seedling growth of Arachis hypogaea. On the other hand, similar to our results, Seven et al. (2015) revealed that $260-\mathrm{nm}$ UV-C radiation administration resulted in a remarkable decrease in germination percentage, weight gain, and root length in A. cepa. According to Darras et al. (2020), while low doses of UV-C radiation cause positive physiochemical changes in the plant, high doses of UV-C exposure cause many growth-restricting changes such as the destruction of photosynthetic pigments and photosystem II damage. Lycopene reduced UV-mediated growth arrest in a dosedependent manner. According to Ascenso et al. (2016), lycopene is the fastest-depleting antioxidant in human skin through UV irradiation and may therefore play an effective protective function against UV. The mitigating effect of lycopene on the growth of UV-exposed Allium may be explain on the basis of the investigation of Fazekas et al. (2003) who reported that lycopene had a promising potential in maintaining normal cell proliferation against UV-induced photodamages.

As reflected in Table 2, there was no significant difference between the lycopene-treated groups (G2 and G3) and the control group (G1) with regard to the genotoxicity parameters. Therefore, it may be suggested that lycopene did not trigger any genotoxicity when administered alone. Our results were in accordance with Ascenso (2012) who reported that pure crystalline and formulated lycopene did not have any genotoxic potential. In addition to not being genotoxic itself, lycopene lessens the genotoxicity of many genotoxins (FernándezBedmar et al. 2018). On the other hand, while 254-nm UV radiation caused a significant decrease in $\mathrm{MI}$ level, it induced a notable increase in both MN and other CAs in G4. UV-C administration induced various CAs in different phases of cell mitosis in $\mathrm{G} 4$ such as $\mathrm{MN}$, fragment, vagrant chromosome, sticky chromosome, bridge, unequal distribution of chromatin, multipolar anaphase, and vacuole nucleus (Fig. 1, Table 2). MN is a small body containing extranuclear chromatin, surrounded by a nuclear membrane. It could be described as an apparent harbinger of genotoxic agents around. MN frequency in UV-exposed G4 was nearly 79-fold of the control group (Fig. 1a). On the other hand, the sharp increase in the frequency of MN, induced by $254 \mathrm{~nm} \mathrm{UV}$, gradually decreased with increasing doses of lycopene. Indeed, MN levels in G5 and G6 treated with lycopene were nearly 65 and 55 times that of the control group, respectively. Our results were consistent with other studies showing that UV-C irradiation clearly induces MN formation (Haaf et al. 1999; Terradas et al. 2012; Seven et al. 2015). According to Hintzsche et al. (2017), acentric fragments as well as entire chromosomes those lagged behind in anaphase and not included into daughter nuclei at telophase are the major reasons of MN formation in dividing cells. Clastogenic factors mainly lead to a rise in the fragment formation which in turn resulted
Table 1 Effects of UV-C and lycopene on physiological parameters

\begin{tabular}{llll}
\hline Groups* $^{*}$ & $\begin{array}{l}\text { Germination percentage } \\
(\%)(n=50)\end{array}$ & $\begin{array}{l}\text { Root length } \\
(\mathrm{cm})(n=10)\end{array}$ & Weight gain $(\mathrm{g})(n=10)$ \\
\hline G1 & 100 & $6.74 \pm 1.28^{\mathrm{a}}$ & $+4.50^{\mathrm{a}}(5.00 \pm 1.46-9.50 \pm 2.68)$ \\
G2 & 100 & $6.80 \pm 1.30^{\mathrm{a}}$ & $+4.62^{\mathrm{a}}(5.12 \pm 1.48-9.74 \pm 2.71)$ \\
G3 & 100 & $6.86 \pm 1.32^{\mathrm{a}}$ & $+4.70^{\mathrm{a}}(4.97 \pm 1.42-9.67 \pm 2.66)$ \\
G4 & 63 & $0.75 \pm 0.46^{\mathrm{d}}$ & $+0.63^{\mathrm{d}}(5.15 \pm 1.50-5.78 \pm 1.60)$ \\
G5 & 71 & $1.60 \pm 0.88^{\mathrm{c}}$ & $+1.53^{\mathrm{c}}(5.10 \pm 1.46-6.63 \pm 1.69)$ \\
G6 & 80 & $3.90 \pm 1.13^{\mathrm{b}}$ & $+2.84^{\mathrm{b}}(4.99 \pm 1.44-7.83 \pm 2.15)$ \\
\hline
\end{tabular}

*G1, control; G2, 215 mg/L lycopene; G3, 430 mg/L lycopene; G4, 254-nm UV radiation; G5, 215 mg/L lycopene + 254-nm UV radiation; G6, $430 \mathrm{mg} / \mathrm{L}$ lycopene + 254-nm UV radiation. The means shown with different letters $(\mathrm{a}-\mathrm{d})$ in the same column were considered as significant at $p<0.05$ 
Table 2 Protective role of lycopene against UV-C-induced genotoxicity

\begin{tabular}{|c|c|c|c|c|c|c|}
\hline Aberrations & G1 & $\mathrm{G} 2$ & G3 & G4 & G5 & G6 \\
\hline MI & $\begin{array}{l}795.60 \\
\quad \pm 24.30^{\mathrm{a}}\end{array}$ & $\begin{array}{l}812.40 \\
\quad \pm 27.38^{\mathrm{a}}\end{array}$ & $\begin{array}{l}809.64 \\
\quad \pm 25.77^{\mathrm{a}}\end{array}$ & $\begin{array}{l}428.80 \\
\quad \pm 14.52^{\mathrm{d}}\end{array}$ & $\begin{array}{l}495.30 \\
\quad \pm 16.78^{\mathrm{c}}\end{array}$ & $\begin{array}{l}554.60 \\
\quad \pm 18.25^{\mathrm{b}}\end{array}$ \\
\hline $\mathrm{MN}$ & $0.54 \pm 0.72^{\mathrm{d}}$ & $0.48 \pm 0.56^{\mathrm{d}}$ & $0.28 \pm 0.36^{\mathrm{d}}$ & $42.70 \pm 5.36^{\mathrm{a}}$ & $35.20 \pm 4.74^{\mathrm{b}}$ & $29.50 \pm 4.12^{\mathrm{c}}$ \\
\hline FRG & $0.00 \pm 0.00^{\mathrm{d}}$ & $0.00 \pm 0.00^{\mathrm{d}}$ & $0.00 \pm 0.00^{\mathrm{d}}$ & $60.40 \pm 7.72^{\mathrm{a}}$ & $52.10 \pm 7.13^{\mathrm{b}}$ & $44.90 \pm 6.38^{\mathrm{c}}$ \\
\hline $\mathrm{VC}$ & $0.00 \pm 0.00^{\mathrm{d}}$ & $0.00 \pm 0.00^{\mathrm{d}}$ & $0.00 \pm 0.00^{\mathrm{d}}$ & $48.60 \pm 6.75^{\mathrm{a}}$ & $40.10 \pm 5.77^{\mathrm{b}}$ & $33.40 \pm 4.97^{\mathrm{c}}$ \\
\hline $\mathrm{SC}$ & $0.32 \pm 0.44^{\mathrm{d}}$ & $0.18 \pm 0.26^{\mathrm{d}}$ & $0.00 \pm 0.00^{\mathrm{d}}$ & $40.20 \pm 4.98^{\mathrm{a}}$ & $33.70 \pm 4.23^{\mathrm{b}}$ & $27.80 \pm 3.59^{\mathrm{c}}$ \\
\hline B & $0.00 \pm 0.00^{\mathrm{d}}$ & $0.00 \pm 0.00^{\mathrm{d}}$ & $0.00 \pm 0.00^{\mathrm{d}}$ & $32.80 \pm 3.24^{\mathrm{a}}$ & $26.90 \pm 2.78^{\mathrm{b}}$ & $20.30 \pm 2.55^{\mathrm{c}}$ \\
\hline UDC & $0.00 \pm 0.00^{\mathrm{d}}$ & $0.00 \pm 0.00^{\mathrm{d}}$ & $0.00 \pm 0.00^{\mathrm{d}}$ & $26.10 \pm 2.88^{\mathrm{a}}$ & $21.40 \pm 2.61^{\mathrm{b}}$ & $17.30 \pm 1.97^{\mathrm{c}}$ \\
\hline MA & $0.00 \pm 0.00^{\mathrm{d}}$ & $0.00 \pm 0.00^{\mathrm{d}}$ & $0.00 \pm 0.00^{\mathrm{d}}$ & $19.70 \pm 1.83^{\mathrm{a}}$ & $13.80 \pm 1.54^{\mathrm{b}}$ & $8.20 \pm 1.22^{\mathrm{c}}$ \\
\hline $\mathrm{VN}$ & $0.00 \pm 0.00^{\mathrm{d}}$ & $0.00 \pm 0.00^{\mathrm{d}}$ & $0.00 \pm 0.00^{\mathrm{d}}$ & $12.80 \pm 1.26^{\mathrm{a}}$ & $8.40 \pm 0.84^{\mathrm{b}}$ & $3.90 \pm 0.64^{\mathrm{c}}$ \\
\hline
\end{tabular}

G1, control; G2, 215 mg/L lycopene; G3, 430 mg/L lycopene; G4, 254-nm UV radiation; G5, 215 mg/L lycopene + 254-nm UV radiation; G6, $430 \mathrm{mg} / \mathrm{L}$ lycopene + 254-nm UV radiation. The means $(n=10)$ shown with different letters (a-d) in the same line were considered as significant at $p<0.05$. MI mitotic index, $M N$ micronucleus, $F R G$ fragment, $V C$ vagrant chromosome, $S C$ sticky chromosome, $B$ bridge, $U D C$ unequal distribution of chromatin, $M A$ multipolar anaphase, $V N$ vacuole nucleus in not correctly distributed chromatins to daughter nuclei and remains as $\mathrm{MN}$ in the cytoplasm. Confirming this, in our study, the most common CAs following MN formation was fragment (Fig. 1b). Fragment formation is an alert for broken DNA in cells. Khlebova et al. (2020) reported that ionizing radiation is an inducer for fragmentation as well as chemical mutagens. Because of the lack of centromeres and kinetochores that allow the chromosomes to move, fragment chromosomes remain immobile and lagged during the anaphase of mitosis. Similar to MN, fragment formation in G5 and G6 gradually decreased with the increased doses of lycopene. Another chromosomal disorder contributing to genomic instability in UV-C-exposed group (G4) was vagrant chromosome which observed in telophase (Fig. 1c) and anaphase (Fig. 1d, f). Elevated vagrant level is a sign for spindle poisoning and usually occurs due to irregularities in chromosomal separation (Sivaram et al. 2020). While the frequency of vagrant in G4 increased to $48.60 \pm 6.75$, low-dose lycopene applied simultaneously with UV-C reduced the vagrant frequency to $40.10 \pm 5.77$ in G5. In addition, G6 had the least vagrant incidence (33.40 \pm 4.97$)$ among UV-C-treated groups. Sticky chromosome was one of the most seen CAs in UV-C-treated G4 (Fig. 1e). Debnath et al. (2020) stated that cellular DNA is a conspicuous target for UV-dependent genetic impairment in plants, and stickiness may be a result of polymeric deterioration of chromosomal DNA. Likewise the above-mentioned CAs, the increase in the amount of lycopene applied simultaneously with UV-C resulted in a gradual decrease in sticky chromosome frequency in G5 and G6. Stickiness is an irreversible disorder and provokes cell death (Siddiqui and Alrumman 2020). Another frequent UV-C-induced CAs types in G4 were bridge formation (Fig. 1f) and unequal distribution of chromatin (Fig. 1g). Chromosomal bridges are usually arisen from fusion and rupture of chromosomes or chromatids
(Luo et al. 2004), while unequal distribution of chromatin occurs due to the non-disjunction of chromatids in anaphase and causes a subsequent increase in vagrant frequency (Dutta et al. 2018). Oladipupo et al. (2021) showed a strong positive correlation between the frequencies of bridges and sticky chromosomes in the meristematic cells of $A$. cepa treated with genotoxic extract of Phaulopsis falcisepala. Two hundred fifty-four-nanometer-UV radiation triggered a stunning increase in multipolar anaphase (Fig. 1h) and vacuole nucleus (Fig. 11) in G4. Multipolarity in mitosis is a warning for agents malfunctioning the centrioles and spindles (Khallef et al. 2019; Khlebova et al. 2020). In addition, Sutan et al. (2014) reported that vacuole nucleus is a kind of CAs which refers to a devastating effect on DNA synthesis in the synthesis phase of the mitosis. Based on bridge, unequal distribution of chromatin, multipolarity, and vacuole nucleus frequencies, like the previously mentioned CAs, the mitigating role of lycopene administration in G5 and G6 treated with both lycopene and UV was also dose-dependent. Our results were in line with the study of Angelova et al. (2020) who showed that prolonged UV irradiation provoked an apparent increase in MN formation in Hordeum vulgare. According to the study performed by Wang and Wang (1999), UV irradiation caused high MN frequency levels in pollen mother cells of Tradescantia. Moreover, Seven et al. (2015) demonstrated that UV-C radiation induced CAs formation in A. cepa roots such as fragment, reverse polarization, stickiness in chromosomes, bridge, binucleated cell, and unequal distribution of chromatin as well as MN. However, this is the first study that revealed the vagrant-, multipolar anaphase-, and vacuole nucleus-inducing effects of UV-C radiation.

MI, a reliable sign for a healthy mitotic activity of cells, exhibited a significant decrease in UV-C-exposed G4. On the other hand, MI level showed a significant improvement in 
Fig. 1 Chromosomal aberrations induced by UV-C radiation (a $\mathrm{MN}$ at interphase, $\mathbf{b}$ fragment at anaphase, $\mathbf{c}$ vagrant chromosome at telophase, $\mathbf{d}$ vagrant chromosome at anaphase, e sticky chromosome, $\mathbf{f}$ bridge at anaphase (dotted arrows) and vagrant chromosome (straight arrows), $\mathbf{g}$ unequal distribution of chromatin, h multipolar anaphase, 1 vacuole nucleus)

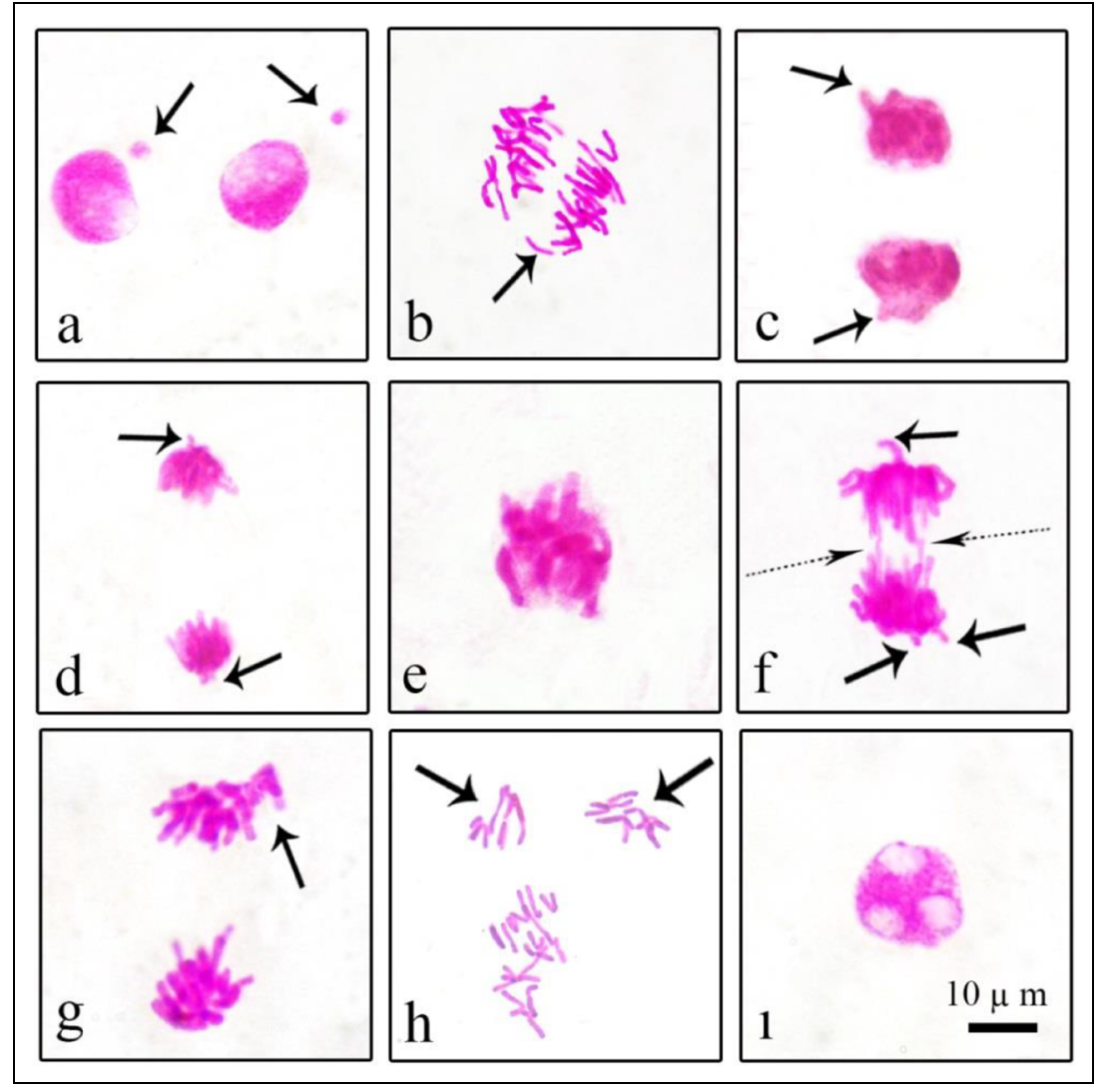

groups treated simultaneously with UV-C and lycopene (G5 and G6) compared to G4, even if it did not rise to the control level (Table 2). Our results on MI were in line with VerdesTeodor et al. (2019) who revealed the mito-depressive effect of UV-C in root meristems of Cucurbita pepo L.

Genotoxicity-extenuating capacity of lycopene against various genotoxins such as aflatoxins and oxygen radicals have already been reported (Fernández-Bedmar et al. 2018). Chromosomal perturbations are potential cancer-starters. Yet, antioxidant features of lycopene have been shown to be effective in suppressing the cancer insurgences (Imran et al.
2020). Sirikhet et al. (2021) suggested that lycopene has more skin-protective properties than beta carotene, as lycopene is a natural antioxidant and has UV-blocking power. According to Ascenso et al. (2016), lycopene pre-treatment seemed to correct photodamage in cells exposed to UV radiation through mitotic modifications.

In order to reveal the effect of UV radiation and lycopene on the oxidative balance of cells, membrane damage and antioxidant enzyme activities were investigated (Table 3). MDA is known to be a decisive biomarker of both redox signaling and lipid peroxidation in biological membranes
Table 3 Effects of UV-C and lycopene on biochemical parameters

\begin{tabular}{llll}
\hline Groups* $^{*}$ & $\begin{array}{l}\text { MDA } \\
\left(\mu \mathrm{M} \mathrm{g}^{-1} \mathrm{FW}\right)(n=3)\end{array}$ & $\begin{array}{l}\text { SOD } \\
\left(\mathrm{U} \mathrm{mg}^{-1} \mathrm{FW}\right)(n=3)\end{array}$ & $\begin{array}{l}\text { CAT } \\
\left(\mathrm{OD}_{240 \mathrm{~nm}} \mathrm{~min}^{-1} \mathrm{FW}\right)(n=3)\end{array}$ \\
\hline G1 & $8.70 \pm 1.86^{\mathrm{d}}$ & $90.40 \pm 7.16^{\mathrm{d}}$ & $0.36 \pm 0.78^{\mathrm{d}}$ \\
G2 & $8.50 \pm 1.84^{\mathrm{d}}$ & $91.50 \pm 7.24^{\mathrm{d}}$ & $0.34 \pm 0.76^{\mathrm{d}}$ \\
G3 & $8.60 \pm 1.82^{\mathrm{d}}$ & $88.30 \pm 7.12^{\mathrm{d}}$ & $0.35 \pm 0.75^{\mathrm{d}}$ \\
G4 & $30.40 \pm 3.27^{\mathrm{a}}$ & $248.60 \pm 15.66^{\mathrm{a}}$ & $0.96 \pm 1.16^{\mathrm{a}}$ \\
G5 & $22.30 \pm 2.94^{\mathrm{b}}$ & $196.20 \pm 13.58^{\mathrm{b}}$ & $0.75 \pm 0.96^{\mathrm{b}}$ \\
G6 & $14.80 \pm 2.15^{\mathrm{c}}$ & $146.90 \pm 10.75^{\mathrm{c}}$ & $0.58 \pm 0.84^{\mathrm{c}}$ \\
\hline
\end{tabular}

*G1, control; G2, 215 mg/L lycopene; G3, 430 mg/L lycopene; G4, 254-nm UV radiation; G5, 215 mg/L lycopene + 254-nm UV radiation; G6, $430 \mathrm{mg} / \mathrm{L}$ lycopene + 254-nm UV radiation. The means shown with different letters $(\mathrm{a}-\mathrm{d})$ in the same column were considered as significant at $p<0.05$ 
(Khoubnasabjafari and Jouyban 2020). Differences in MDA levels of the first three groups (G1, G2, and G3) were not statistically significant. However, MDA amount of UV-Ctreated G4 was about 3.5 times that of the control group indicating that an oxidative imbalance took place following UV exposure in A. cepa roots. Our results were in accordance with the data of Luo et al. (2019) who revealed that UV-C administration triggered a remarkable induction in MDA levels in grape leaves. Another study on Nicotiana tabacum callus showed that 254-nm UV radiation caused a remarkable increase in MDA accumulation from the $6^{\text {th }}$ hour of application (Zacchini and de Agazio 2004). Lycopene decreased MDA levels in G5 and G6, depending on the dose when applied with UV-C. dos Santos et al. (2015) stated that lycopene owned a suppressive potential in the propagation stage of lipid peroxidation. In addition, lycopene was proven to reduce oxidative stress-related lipid peroxidation in bovine sperm cells (Tvrdá et al. 2016). Lycopene contributes to the protection of membrane integrity by removing the radicals such as singlet oxygen and peroxyl radicals, owing to the double bonds in its structure (Caseiro et al. 2020).

Lipid peroxidation and destruction of chromosomes are among the consequences of oxidative stress arisen from over-production of ROS in cells (Xie et al. 2019). Plants are endowed with antioxidant systems to overcome the menacing accumulation of these radicals. SOD and CAT are the enzymatic antioxidants those have major roles in removing the oxidative stress by scavenging superoxide and hydrogen peroxide radicals, respectively. The total SOD and CAT activities of the G1, G2, and G3 were not statistically significant (Table 3 ). On the other hand, $254 \mathrm{~nm}$ UV initiated a sharp increase in the total activities of SOD and CAT. In G4, the total SOD and CAT activities were 2.75 and 2.67 times those of the control (G1), respectively. Our results were consistent with Zacchini and de Agazio (2004), who reported that 254-nm UV radiation led to a rise in the activities of antioxidant enzymes, including CAT. Similar to our data, Acemi et al. (2018) reported that in Amsonia orientalis, prolonged UV-C exposure resulted in significant increases in MDA level and CAT activity but delayed root growth. In pea plants, it has been shown that UV-C-induced oxidative stress causes notable increases in MDA content and the activities of SOD and CAT enzymes (Sergiev et al. 2017). In addition, UV-B radiation has been shown to induce an increase in oxidative stress mediated by the production of ROS (Ascenso et al. 2016; Liu et al. 2019). Lycopene considerably reduced the activities of SOD and CAT when applied with UV in G5 and G6 compared to G4. Grabowska et al. (2019) stated that lycopene performed wonderfully in quenching ROS to alleviate the dangers of oxidative stress, including cancer. According to Imran et al. (2020), lycopene is a miracle compound that participates in free-radical scavenging, chelating, and anti-apoptotic actions in case of oxidative imbalance in cells. There are a number of studies showing that dietary lycopene intake modifying the antioxidant enzyme activities including SOD and CAT (Jiang et al. 2016; Li et al. 2017; Uçar and Pandir 2017). However, this is the first study that revealed the mitigative potential of lycopene against UV-C-mediated oxidative attack.

Table 4 illustrates the extenuating capacity of lycopene against UV-C-induced meristematic cell damages. According to the intensity of the damages, they were classified as "no damage," "slight damage," "moderate damage," and "severe damage." Lycopene-treated G2 and G3 did not display any kind of damage in meristematic tissue, similar to the control group. In G4, UV-C-induced meristematic damages were listed as epidermis cell damage, necrosis, giant cell nucleus, cortex cell damage, and indistinct transmission tissue (Table 4, Fig. 2). Among these defects, epidermis cell damage and cortex cell damage were severe, while the others were observed at moderate levels. Modifications in UV-C-irradiated root tissues of Capsicum species has already been mentioned by Kareem et al. (2019). Zhang et al. (2020) reported that UV-B irradiation induced the death of the root tip cells in Arabidopsis. In our study, meristematic damages induced by 254-nm UV radiation point out serious risks that may result in cell death. Giant cell nucleus is a marker of damaged mitosis similar to the aberrant chromosomes. Malformation in transmission tissue could be one of the most likely causes of retardation in growth parameters due to reduced water uptake. Lycopene reduced damage levels depending on the dose when applied with UV-C. Our results were consistent with the study of Kalefetoğlu Macar et al. (2020) who reported the healing effect of

Table 4 Protective role of lycopene against UV-C-induced meristematic cell damages

\begin{tabular}{llllll}
\hline Groups & \multicolumn{2}{l}{ Damages* } & & & \\
\cline { 2 - 6 } & ECD & $\mathrm{N}$ & GCN & CCD & ITT \\
\hline G1 & - & - & - & - & - \\
G2 & - & - & - & - & - \\
G3 & - & - & - & - & - \\
G4 & +++ & ++ & ++ & +++ & ++ \\
G5 & ++ & + & + & ++ & + \\
G6 & + & + & - & + & - \\
\hline
\end{tabular}

G1, control; G2, 215 mg/L lycopene; G3, 430 mg/L lycopene; G4, 254 $\mathrm{nm}$ UV radiation; G5, $215 \mathrm{mg} / \mathrm{L}$ lycopene + 254-nm UV radiation; G6, $430 \mathrm{mg} / \mathrm{L}$ lycopene + 254-nm UV radiation. $* E C D$ epidermis cell damage, $N$ necrosis, $G C N$ giant cell nucleus, $C C D$ cortex cell damage, ITT indistinct transmission tissue. $(-)$ no damage, $(+)$ slight damage, $(++)$ moderate damage, $(+++)$ severe damage 


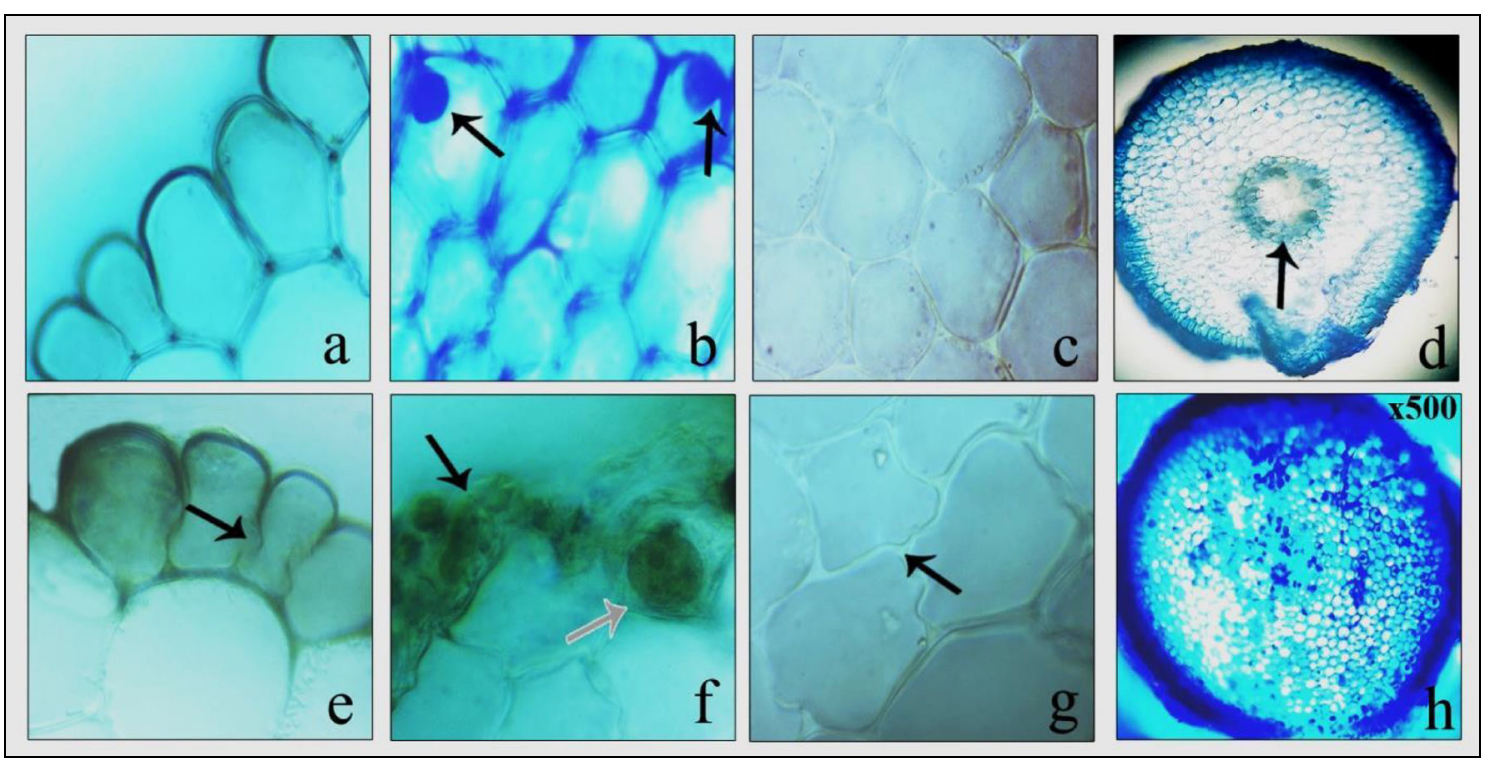

Fig. 2 Meristematic cell damages induced by UV-C administration (a normal appearance of epidermis cells, $\mathbf{b}$ normal appearance of cell nucleus (oval), $\mathbf{c}$ normal appearance of cortex cells, $\mathbf{d}$ normal appearance of

lycopene on Allium roots exposed to cobalt stress. However, the present study is the first to demonstrate the reducing effect of lycopene against the disintegrating effect of UV-C on root meristematic tissues.

\section{Conclusion}

The present study was conducted in today's pandemic conditions where the use of UV-C radiation in sterilization is increasing. Based on the results of this study, we concluded that the deleterious effects of 254-nm UV-C radiation on A. cepa, a well-established model organism, were demonstrated by a detailed research. UV-C has been proven to be a risk factor for growth, oxidative balance, genetic stability, and meristematic cell integrity in A. cepa. The data clearly showed that UV-C was effective not only on microorganisms but also on other non-target organisms, suggesting that UV-C-based sterilization practices may also be dangerous for human health. The fact that lycopene application did not cause adverse effects was one of the important outcomes of the study. Lycopene as a cheap, reliable, and plant-based compound with no side effects had an extenuating capacity on against 254-nm UV-C radiation. According to the data of this research, lycopene supplements and lycopene-rich diet promise an extraordinary protection against health problems induced by UV-C exposure. In order to reinforce our findings, similar studies should be designed with other test systems. Biological reactions occur depending on the wavelength of UV light. For this reason, it should not be overlooked that it is extremely important to conduct similar studies with different UV types. transmission tissue, e epidermis cell damage, f necrotic areas (black arrow), giant cell nucleus (white arrow), $\mathbf{g}$ cortex cell damage, $\mathbf{h}$ indistinct appearance of transmission tissue)

Authors' contributions Dr. Dilek Çavuşoğlu, Dr. Tuğçe Kalefetoğlu Macar, Dr. Oksal Macar, Dr. Kültiğin Çavuşoğlu, and Dr. Emine Yalçın carried out the experimental stages, manuscript preparation, and statistical analysis.

Data availability All data and materials generated, utilized, or analyzed during this study are included in this published article.

\section{Declarations}

Ethics approval Not applicable.

Consent to participate Not applicable.

Consent for publication All authors whose names appear on the submission approved the version to be published and agree to be accountable for all aspects of the work in ensuring that questions related to the accuracy or integrity of any part of the work are appropriately investigated and resolved.

Conflict of interest The authors declare no competing interests.

\section{References}

Acemi A, Duman YA, Karakuș YY, Özen F (2018) A preliminary investigation on developmental and biochemical responses of Amsonia orientalis to ultraviolet-C irradiation. Adv Hortic Sci 32(4):563-568

Andersen BM, Bånrud H, Bøe E, Bjordal O, Drangsholt F (2006) Comparison of UV C light and chemicals for disinfection of surfaces in hospital isolation units. Infect Control Hosp Epidemiol 27(7): 729-734

Angelova T, Tyutyundzhiev N, Angelov C, Gateva S, Jovtchev G (2020) Induction of micronuclei after prolonged UV irradiation of Poaceae species cultivated in laboratory conditions and wild-growing in Rila Mountain. RAD Conference Proceedings 4:39-44 
Ascenso A (2012) Carrier-mediated dermal delivery for prevention or treatment of skin disorders. Jenny Stanford Publishing

Ascenso A, Pedrosa T, Pinho S, Pinho F, Oliveira JMP, Cabral Marques H, Oliveira H, Simões S, Santos C (2016) The effect of lycopene preexposure on UV-B-irradiated human keratinocytes. Oxidative Med Cell Longev 2016:8214631

Atik M, Karagüzel O, Ersoy S (2007) Sicaklığın Dalbergia sissoo tohumlarının çimlenme özelliklerine etkisi. Mediterr Agric Sci 20(2):203-210

Beauchamp C, Fridovich I (1971) Superoxide dismutase: improved assays and an assay applicable to acrylamide gels. Anal Biochem 44: 276-287

Bernhard GH, Neale RE, Barnes PW, Neale PJ, Zepp RG, Wilson SR, Andrady AL, Bais AF, McKenzie RL, Aucamp PJ, Young PJ, Liley JB, Lucas RM, Yazar S, Rhodes LE, Byrne SN, Hollestein LM, Olsen CM, Young AR, Robson TM, Bornman JF, Jansen MAK, Robinson SA, Ballaré CL, Williamson CE, Rose KC, Banaszak AT, Häder D-P, Hylander S, Wängberg S-Å, Austin AT, Hou W-C, Paul ND, Madronich S, Sulzberger B, Solomon KR, Li H, Schikowski T, Longstreth J, Pandey KK, Heikkilä AM, White CC (2020) Environmental effects of stratospheric ozone depletion, UV radiation and interactions with climate change: UNEP Environmental Effects Assessment Panel, update 2019. Photochem Photobiol Sci 19(5):542-584

Bramley PM (2000) Is lycopene beneficial to human health? Phytochemistry 54(3):233-236

Caseiro M, Ascenso A, Costa A, Creagh-Flynn J, Johnson M, Simões S (2020) Lycopene in human health. LWT 127:109323

Coohill TP, Sagripanti JL (2008) Overview of the inactivation by $254 \mathrm{~nm}$ ultraviolet radiation of bacteria with particular relevance to biodefense. Photochem Photobiol 84(5):1084-1090

Darras AI, Tsikaloudakis G, Lycoskoufis I, Dimitriadis C, Karamousantas D (2020) Low doses of UV-C irradiation affects growth, fruit yield and photosynthetic activity of tomato plants. Sci Hortic 267:109357

Debnath P, Mondal A, Sen K, Mishra D, Mondal NK (2020) Genotoxicity study of nano $\mathrm{Al} 2 \mathrm{O} 3, \mathrm{TiO} 2$ and $\mathrm{ZnO}$ along with UV-B exposure: An Allium cepa root tip assay. Sci Total Environ 713:136592

dos Santos PP, Paese K, Guterres SS, Pohlmann AR, Costa TH, Jablonski A, Hickmann Flôres S, de Rios AO (2015) Development of lycopene-loaded lipid-core nanocapsules: physicochemical characterization and stability study. J Nanopart Res 17(2):107

Dutta J, Ahmad A, Singh J (2018) Study of industrial effluents induced genotoxicity on Allium cepa L. Caryologia 71(2):139-145

Fazekas Z, Gao D, Saladi RN, Lu Y, Lebwohl M, Wei H (2003) Protective effects of lycopene against ultraviolet B-induced photodamage. Nutr Cancer 47(2):181-187

Fenech M, Chang WP, Kirsch-Volders M, Holland N, Bonassi S, Zeiger E (2003) HUMN Project: detailed description of the scoring criteria for the cytokinesis-block micronucleus assay using isolated human lymphocyte cultures. Mutat Res 534:65-75

Fernández-Bedmar Z, Anter J, Alonso Moraga Á (2018) Anti/genotoxic, longevity inductive, cytotoxic, and clastogenic-related bioactivities of tomato and lycopene. Environ Mol Mutagen 59(5):427-437

Forges M, Bardin M, Urban L, Aarrouf J, Charles F (2020) Impact of UV-C radiation applied during plant growth on pre-and postharvest disease sensitivity and fruit quality of strawberry. Plant Dis 104(12): 3239-3247

Fukui T, Niikura T, Oda T, Kumabe Y, Ohashi H, Sasaki M, Igarashi T, Kunisada M, Yamano N, Oe K, Matsumoto T, Matsushita T, Hayashi S, Nishigori C, Kuroda R (2020) Exploratory clinical trial on the safety and bactericidal effect of 222-nm ultraviolet $\mathrm{C}$ irradiation in healthy humans. PLoS One 15(8):e0235948

Golob A, Kavčič J, Stibilj V, Gaberščik A, Vogel-Mikuš K, Germ M (2017) The effect of selenium and UV radiation on leaf traits and biomass production in Triticum aestivum L. Ecotoxicol Environ Saf 136:142-149

Grabowska M, Wawrzyniak D, Rolle K, Chomczyński P, Oziewicz S, Jurga S, Barciszewski J (2019) Let food be your medicine: nutraceutical properties of lycopene. Food Funct 10(6):3090-3102

Guerrero-Beltrán JA, Barbosa-Cánovas GV (2004) Advantages and limitations on processing foods by UV light. Food Sci Technol Int 10(3):137-147

Haaf T, Raderschall E, Reddy G, Ward DC, Radding CM, Golub EI (1999) Sequestration of mammalian Rad51-recombination protein into micronuclei. J Cell Biol 144(1):11-20

Heath RL, Packer L (1968) Photoperoxidation in isolated chloroplasts: II. Role of electron transfer. Arch Biochem Biophys 125(3):850-857

Hill HD, Myers WM (1945) A schedule including cold treatment to facilitate somatic chromosome counts in certain forage grasses. Stain Technol 20:89-92

Hintzsche H, Hemmann U, Poth A, Utesch D, Lott J, Stopper H (2017) Fate of micronuclei and micronucleated cells. Mutat Res Rev Mutat Res 771:85-98

Imran M, Ghorat F, Ul-Haq I, Ur-Rehman H, Aslam F, Heydari M, Shariati MA, Okuskhanova E, Yessimbekov Z, Thiruvengadam M, Hashempur MH, Rebezov M (2020) Lycopene as a natural antioxidant used to prevent human health disorders. Antioxidants 9(8): 706

Jeon MJ, Ha JW (2018) Efficacy of UV-A, UV-B, and UV-C irradiation on inactivation of foodborne pathogens in different neutralizing buffer solutions. LWT 98:591-597

Jiang W, Guo MH, Hai X (2016) Hepatoprotective and antioxidant effects of lycopene on non-alcoholic fatty liver disease in rat. World $\mathrm{J}$ Gastroenterol 22:10180-10188

Kaidzu S, Sugihara K, Sasaki M, Nishiaki A, Igarashi T, Tanito M (2019) Evaluation of acute corneal damage induced by $222-\mathrm{nm}$ and 254-nm ultraviolet light in Sprague-Dawley rats. Free Radic Res 53(6):611617

Kalefetoğlu Macar T, Macar O, Çavuşoğlu K (2020) Protective role of lycopene against meristematic cell damage induced by cobalt (II) nitrate. In: Bashar I (ed) Karadeniz 3. Uluslararası Uygulamalı Bilimler Kongresi Tam Metin Kitabı, Uluslararası Bilimler Akademisi, Türkiye, pp 209-216

Kareem KA, Olobatoke TJ, Rahaman AA, Mustapha OT (2019) Mutagenic effects of ultraviolet (UV-C) irradiation on the anatomy of three species of Capsicum. Bangladesh J Sci Ind Res 54(2):111116

Khallef M, Benouareth DE, Konuk M, Liman R, Bouchelaghem S, Hazzem S, Kerdouci K (2019) The effect of silver nanoparticles on the mutagenic and the genotoxic properties of the urban wastewater liquid sludges. Environ Sci Pollut Res 26(18):18403-18410

Khlebova LP, Sokolova GG, Brynzova SE (2020) Genotoxicity assessment of bottom sediments of the Chumysh River using the Alliumtest. IOP Conf Ser Earth Environ Sci 543(1):012023

Khoubnasabjafari M, Jouyban A (2020) Challenges on determination of malondialdehyde in plant samples. Arch Crop Sci 4(1):64-66

Kong KW, Khoo H-E, Prasad KN, Ismail A, Tan C-P, Rajab NF (2010) Revealing the power of the natural red pigment lycopene. Molecules 15(2):959-987

Li W, Jiang B, Cao X, Xie Y, Huang T (2017) Protective effect of lycopene on fluoride-induced ameloblasts apoptosis and dental fluorosis through oxidative stress mediated Caspase pathways. Chem Biol Interact 261:27-34

Lindblad M, Tano E, Lindahl C, Huss F (2020) Ultraviolet-C decontamination of a hospital room: amount of UV light needed. Burns 46(4): 842-849

Liu G, Huang Y, Reis FS, Song D, Ni H (2019) Impact of nutritional and environmental factors on inflammation, oxidative stress, and the microbiome 2019. Biomed Res Int 2019:5716241 
Luo LZ, Werner KM, Gollin SM, Saunders WS (2004) Cigarette smoke induces anaphase bridges and genomic imbalances in normal cells. Mutat Res 554:375-385

Luo YY, Li RX, Jiang QS, Bai R, Duan D (2019) Changes in the chlorophyll content of grape leaves could provide a physiological index for responses and adaptation to UV-C radiation. Nord J Bot 37(4): $\mathrm{e} 02314$

Macar O, Macar TK, Çavușoğlu K, Yalçın E (2020) Determination of protective effect of carob (Ceratonia siliqua L.) extract against cobalt (II) nitrate-induced toxicity. Environ Sci Pollut Res 27(32): 40253-40261

Mullenders LH (2018) Solar UV damage to cellular DNA: from mechanisms to biological effects. Photochem Photobiol Sci 17(12):18421852

Neelamegam R, Sutha T (2015) UV-C irradiation effect on seed germination, seedling growth and productivity of groundnut (Arachis hypogaea L.). Int J Curr Microbiol App Sci 4(8):430-443

Oladipupo AR, Alaribe CS, Akintemi TA, Coker HA (2021) Effect of Phaulopsis falcisepala (Acanthaceae) leaves and stems on mitotic arrest and induction of chromosomal changes in meristematic cells of Allium cepa. Prog Chem Biochem Res 4(2):134-147

Park MH, Kim JG (2015) Low-dose UV-C irradiation reduces the microbial population and preserves antioxidant levels in peeled garlic (Allium sativum L.) during storage. Postharvest Biol Technol 100: 109-112

Roy B, Krishnan SP, Chandrasekaran N, Mukherjee A (2019) Toxic effects of engineered nanoparticles (metal/metal oxides) on plants using Allium cepa as a model system. Compr Anal Chem 84:125143

Sergiev I, Todorova D, Katerova Z, Shopova E, Jankauskiene J, Jurkoniene S (2017) Beneficial effects of auxin-like compounds on pea plants irradiated with UV-C. Genet Plant Physiol 7(3-4): 135-146

Seven B, Çavuşoğlu K, Yalçın E, Çavuşoğlu K (2015) Allium cepa L.(Amarylidaceae) kök ucu hücreleri üzerine ultraviyole radyasyonun fizyolojik ve genotoksik etkilerinin araștirilmasi. CFD 36(5):24-31

Sharma PC, Gupta PK (1982) Karyotypes in some pulse crops. Nucleus 25:181-185

Siddiqui S, Alrumman S (2020) Cytological changes induced by clethodim in Pisum sativum plant. Bangladesh J Bot 49(2):367-374

Sirikhet J, Chanmahasathien W, Raiwa A, Kiattisin K (2021) Stability enhancement of lycopene in Citrullus lanatus extract via nanostructured lipid carriers. Food Sci Nutr 9(3):1750-1760

Sivaram AK, Panneerselvan L, Surapaneni A, Shah K, Crosbie N, Rogers Z, Lee E, Venkatraman K, Kannan K, Naidu R, Megharaj M (2020) Evaluation of cyto-genotoxicity of perfluorooctane sulfonate (PFOS) to Allium cepa. Environ Toxicol Chem:1-7

Srivastava AK, Singh D (2020) Assessment of malathion toxicity on cytophysiological activity, DNA damage and antioxidant enzymes in root of Allium cepa model. Sci Rep 10(1):1-10
Sutan NA, Popescu A, Mihaescu C, Soare LC, Marinescu MV (2014) Evaluation of cytotoxic and genotoxic potential of the fungicide Ridomil in Allium cepa L. An Stiint Univ Al I Cuza Iasi 60(1):5-12

Szoltysek K, Walaszczyk A, Janus P, Kimmel M, Widlak P (2017) Irradiation with UV-C inhibits TNF- $\alpha$-dependent activation of the $\mathrm{NF}-\mathrm{KB}$ pathway in a mechanism potentially mediated by reactive oxygen species. Genes Cells 22(1):45-58

Terradas M, Martín M, Hernández L, Tusell L, Genescà A (2012) Nuclear envelope defects impede a proper response to micronuclear DNA lesions. Mutat Res-Fund Mol M 729(1-2):35-40

Tvrdá E, Kováčik A, Tušimová E, Paál D, Mackovich A, Alimov J, Lukáč N (2016) Antioxidant efficiency of lycopene on oxidative stress-induced damage in bovine spermatozoa. J Anim Sci Biotechnol 7:50

Uçar S, Pandir D (2017) Furan induced ovarian damage in non-diabetic and diabetic rats and cellular protective role of lycopene. Arch Gynaecol Obstet 296:1027-1037

Verdaguer D, Jansen MA, Llorens L, Morales LO, Neugart S (2017) UVA radiation effects on higher plants: exploring the known unknown. Plant Sci 255:72-81

Verdes-Teodor A, Vochita G, Creanga D (2019) On some genotoxic effects of UV-C radiation in root meristems in Cucurbita pepo L. Rom Rep Phys 71:707

Wang S, Wang X (1999) The Tradescantia-micronucleus test on the genotoxicity of UV-B radiation. Mutat Res-Fund Mol M 426(2): $151-153$

Xie X, He Z, Chen N, Tang Z, Wang Q, Cai Y (2019) The roles of environmental factors in regulation of oxidative stress in plant. BioMed Res Int 2019:9732325

Yadav A, Singh D, Lingwan M, Yadukrishnan P, Masakapalli SK, Datta S (2020) Light signaling and UV-B-mediated plant growth regulation. J Integr Plant Biol 62(9):1270-1292

Yin Y, Zheng Z, Jiang Z (2019) Effects of lycopene on metabolism of glycolipid in type 2 diabetic rats. Biomed Pharmacother 109:2070 2077

Yu SL, Lee SK (2017) Ultraviolet radiation: DNA damage, repair, and human disorders. Mol Cell Toxicol 13(1):21-28

Zacchini M, de Agazio M (2004) Spread of oxidative damage and antioxidative response through cell layers of tobacco callus after UV-C treatment. Plant Physiol Biochem 42(5):445-450

Zhang H, Jiang Y, He Z, Ma M (2005) Cadmium accumulation and oxidative burst in garlic (Allium sativum). J Plant Physiol 162(9): 977-984

Zhang P, Wang R, Wang Y, Xu J (2020) Ultraviolet-B radiation induces cell death in root tips and reprograms metabolism in Arabidopsis. Biol Plant 64:764-772

Zou J, Yue J, Jiang W, Liu D (2012) Effects of cadmium stress on root tip cells and some physiological indexes in Allium cepa var. agrogarum L. Acta Biol Cracov Ser Bot 54:129-141

Publisher's note Springer Nature remains neutral with regard to jurisdictional claims in published maps and institutional affiliations. 